\title{
The design of innovative and entrepreneurial courses of mechanical majors against the background of new engineering
}

\author{
Chu Diao Huang, Jian-Wen Guo ${ }^{a_{*} *}$, Li Xie, Xiao Chang Cao
}

College of Mechanical Engineering, Dongguan University of Technology, Dongguan, GuangDong, 523808, China

agiven_gjw@163.com

Keywords: new engineering, mechanical majors, innovation and entrepreneurship, courses.

\begin{abstract}
Against the background of new engineering, setting up innovative and entrepreneurial courses in mechanical majors is to foster students an ability to design and develop innovative products and to start up business preliminarily by taking advantage of their relevant engineering and technical knowledge. Take the course of Integrated Project Design as an example, in this course, we reform educational and teaching methods and design an execute solution, which provide a reference for mechanical majors to take innovative and entrepreneurial courses.
\end{abstract}

\section{Introduction}

The new round technological revolution and industrial transformation is accelerating and the competition in overall national strength is fiercer. The new booming economy which is characteristic of new technology, new condition and new industry asks engineering talents for higher ability of innovation and entrepreneurship and of transboundary integration to boost economic transformation and upgrading. Given that the majors engineering college students are learning is relative directly to all industries which will influence national economy, engineering college students are bound to take part in innovation and entrepreneurship activities directly or indirectly in the future, so having an awareness of innovation and entrepreneurship and grasping the skills of them have been the requirements for engineering college students in the new period.

At present, the scale of Chinese higher engineering education ranks the first around the world. China has been worthy of the name-engineering educational power. Recent years, Chinese higher engineering education has made remarkable progress in many aspects, such as educational quality, students' integrated development, graduates' entrepreneurship and employment and services to help to build our country's modernization. However, there are many problems at the same time disturbing reform and development of Chinese higher engineering education, such as engineering education's lack of practice and teachers' lack of awareness and ability to start engineering education, single teaching method, shortage of practice platform and guidance and support. Therefore, Chinese engineering colleges respond to national strategic needs and start to build new engineering. New engineering requires that higher engineering education should move forward a single step to free minds and promote reform and innovation of established engineering majors, accelerating to explore approaches to train innovative engineering technical talents. It also asks urgently engineering colleges constantly probe new mode of innovation and entrepreneurship education and more modernized applied courses to strengthen engineering college students' education of innovation and entrepreneurship so that to cultivate creative engineering technical talents.

Ministry of Education of China suggests that all colleges should promote to combine major education and innovation and entrepreneurship education organically and adjust the arrangement of major courses according to talent training orientation and target requirements of innovation and entrepreneurship education. Colleges are also supposed to dig out and enrich the educational resources of innovation and entrepreneurship of various major courses and then strengthen innovation and entrepreneurship education during teaching major knowledge. Therefore, innovation 
and entrepreneurship education has been the most important part in the arrangement of subjects in universities [1].

Mechanical majors are an essential part of engineering majors in universities. Against the background of new engineering, setting up innovation and entrepreneurship courses in mechanical majors is to foster students an ability to design and develop innovative products taking advantage of their relevant engineering and technical knowledge and start up their own business when some circumstances are ready [2]. However, while manufacturing skills update rapidly and manufacturing market demands change endlessly, how to combine innovation and entrepreneurship teaching and practice is the problem needed to be solved cautiously in the process of innovation and entrepreneurship courses teaching in mechanical majors [3]. This thesis, take the course Integrated Project Design as an example, reforms educational teaching methods and sets up innovation and entrepreneurship courses practice of mechanical majors.

\section{Course objectives}

Development of engineering drawing ability for $3 \mathrm{E}$ is a kind of teaching mode which relies on engineering drawing courses and uses innovative teaching measures to enable students to master the skills of engineering drawing and to improve the professional ability. This training mode is shown in figure 1.

The objectives of Integrated Project Design are as follow.

(1) Let students own an essential and innovative mind: design teaching content according to the features and orientation of this course, introduce the newest development achievement and reform and research achievement of teaching into the course, also, strengthen innovative practice teaching and improve students' innovative mind.

(2) Let students own the ability of independent study and cooperative learning: according to course content and students' features, improve teaching methods and teaching evaluation system, activate students' enthusiasm effectively, lead students to think energetically and enjoy practice, encourage them to study independently and cooperatively.

(3) Let students own a necessary ability of intellectual property protection: intensify the combination of the school resources and outside resources, carry out application practice of intellectual property, promote students' ability of intellectual property protection.

(4) Make students understand the basic knowledge of entrepreneurship: help students understand the skills of integrating entrepreneurship resources and writing entrepreneurship scheme, make students have a preparatory comprehension and thinking about entrepreneurship process, initially cultivate students an awareness and an ability to push their own work, services and skills to market.

(5) Make students establish a scientific view of entrepreneurship: forwardly adapt to the demands of national economic and social development and of human's integrated development, correctly understand the relation of entrepreneurship and career development, obey the rule of entrepreneurship consciously, actively devote to entrepreneurship practice.

\section{Implementation}

Implementation of the course is shown in figure 1. All parts are as follow. 


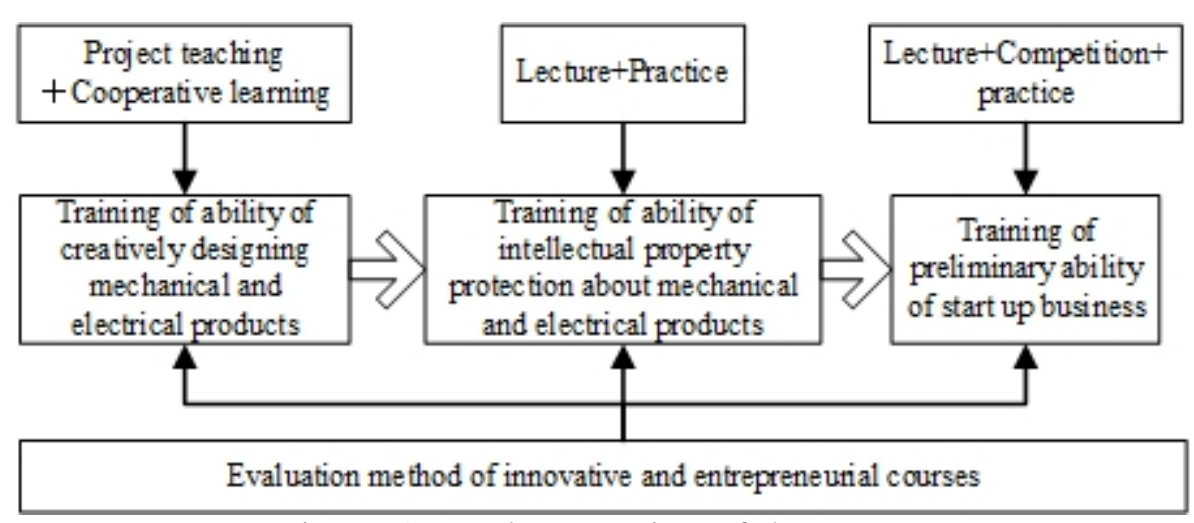

Figure 1. Implementation of the course

\subsection{Composition of the course}

The core of this kind of training is to enhance students' spatial imaginative ability and drawing capacity. The training adopts engineering drawing teaching system-Virtual Reality to assist students to study. The Virtual Reality based on mechanical drawing system is explained in our previous research [3]. The system is realized by VRML and Java. According to the teaching process of mechanical drawing course, this system provides Virtual Reality to support students to learn by themselves. Through this system, students can have interaction with relevant virtual object or event in the virtual environment and realize the perception of 3D Model. Figure 2 is the system interface.

The course is made up of the following three parts:

(1) Training of ability of creatively designing mechanical and electrical products

Depending on different projects, students form different groups which is led by a tutor. The project tutor needs to organize students to design creatively by the form of project(case), which emphasizes that the tutor should guide students to grasp the skills of designing products creatively during the process. Innovation of mechanical and electrical products is the key point in this part, so tutors are required to use innovative projects based on students' knowledge level and the projects should be those that have been introduced into market and are easy to be transformed into products. At the same time, tutors should organize students to participate in applying innovative projects.

(2) Training of ability of intellectual property protection about mechanical and electrical products

Invite patent agents hold some lectures aimed at students' invention, patent application and software copyright application which can cultivate students' awareness and ability of applying for a patent. Project tutors guide students to sort out their achievements of innovative design of mechanical and electrical products and practise to apply for intellectual property.

(3) The training of preliminary ability of start up business

Invite entrepreneurship tutors to give lessons, letting students have a elementary understand and thinking about financing, production, management, sales, risks and control. Foster students' awareness and ability of pushing their own works, services and skills to market. Organize students to sell products, provide skills service and bid for technical scheme. Organize students to take part in innovation and entrepreneurship competition held in country, provinces and cities annually.

\subsection{The teaching measures and methods of the course}

(1) The ability training part of creatively designing mechanical and electrical products includes project team, project teaching and cooperative learning: (a) project team: teachers being the project tutor, students choosing a project tutor, teachers and students form a creative project team to do project practice. (b) project teaching: project tutor teaches students how to be innovative through the real tasks and helps them be familiar with the whole process so that students can learn from existed experiences when they try to be innovative. (c) cooperative learning: after giving real innovative tasks, students in every team should design a specific product scheme under their tutor's guidance and write down their designed scheme. Organize experts to make comments on each 
group's product and choose excellent ones to analyse seriously. Organize students form a creative project team to take part in products designing match which can improve students' zeal.

(2) The training part of intellectual property protection ability about mechanical and electrical products is carried out through the way of lecture and practice. Invite experts from patent office to give lectures to teach students the skills of applying for a patent. Project tutors organize students in the innovative project team to search information, according to their project achievement, to write patent declaration or software copyright declaration and to do the practice of applying for a patent.

(3) The training part of preliminary entrepreneurship ability is taken through lecture, competition and practice. Invite industrial tutors to share the basic knowledge about entrepreneurship, product sales, commodity circulation and corporate running. Organize students to join in various entrepreneurship contest. Do practice about products selling and skills services through Internet or other platforms.

\subsection{Evaluation mode}

This course is carried out through examine. Students' scores are consisted of three parts. The first part is students' ability of creative design (50\%). The second part is students' ability of applying for a patent (25\%). The third part is students' ability of entrepreneurship (25\%). Students' innovation ability is judged by their project tutor. Students' score of patent application is given according to their application situation. The judgement of students' entrepreneurship ability is done by teachers from course team.

\section{Conclusion}

Against the background of new engineering, setting up innovative and entrepreneurial courses in mechanical majors is to foster students an ability to design and develop innovative products and to start up business preliminarily by taking advantage of their relevant engineering and technical knowledge. Take the course of Integrated project design as an example, in this course, we design an execute solution and foster students an ability to design and develop innovative products and to start up business preliminarily by taking advantage of their relevant engineering and technical knowledge, which provide a reference for mechanical majors to take innovative and entrepreneurial courses.

\section{Acknowledgments}

The study was supported by the Project of Department of Education of Guangdong Province (Project Name: Research of Witkey-Based Teaching Pattern of Innovative and Entrepreneurial Practice for Mechanical Specialty), the Project of Education of Dongguan University of Technology (Project Name: Mechanical Drawing Teaching Team), the Project of Education of Dongguan University of Technology (Project Name: Reform and Improvement of Teaching Quality of Mechanical Basic Courses Based on the Cultivation of Innovative Talents), the Project of Education of Dongguan University of Technology (Project Name: Design Thinking and Expression), the Project of Education of Dongguan University of Technology (Project Name: Innovation and entrepreneurship curriculum construction of "Integrated project design"), the Dongguan Social Science and Technology Development Project (NO.2013108101011, NO.2017507140058, NO.2017507140059), and Dongguan Industrial Science and Technology Development Project (NO.2015222119).

\section{References}

[1] Saskia H and Henk S 2012 IEEE Engineering Management Review 40 164-74

[2] Guo J W, Cao X C, Huang H Y, Xie L, Sun Z Z and Wu G H, 2017 2nd Int. Conf. On Electrical And Electronics: Techniques and Applications (Beijing) p237

[3] Jian-Wen Guo et al 2017 IOP Conf. Ser.: Mater. Sci. Eng. 242012070 